\title{
Effects of Growth Hormone and Insulin-like Growth Factor I on Rabbit Proximal Convoluted Tubule Transport
}

Raymond Quigley and Michel Baum

Departments of Pediatrics and Medicine, The University of Texas Southwestern Medical Center at Dallas, Dallas, Texas 75235-9063

\begin{abstract}
This in vitro microperfusion study examined the effects of growth hormone and insulin-like growth factor I (IGF-I) on proximal convoluted tubule (PCT) transport. Tubules were perfused with an ultrafiltrate-like solution and bathed in a serumlike albumin solution. Neither a physiologic $\left(5 \times 10^{-10} \mathrm{M}\right)$, nor a pharmacologic $\left(5 \times 10^{-8} \mathrm{M}\right)$ dose of growth hormone had an effect on PCT phosphate or bicarbonate transport, or volume absorption. Addition of $5 \times 10^{-9} \mathrm{M}$ and $5 \times 10^{-8} \mathrm{M}$ IGF-I, but not $5 \times 10^{-10} \mathrm{M}$ IGF-I, to the bathing solution resulted in an increase (12-15\%) in phosphate transport, but no change in volume absorption or bicarbonate transport. Addition of IGF-I to the luminal perfusate also stimulated phosphate transport. The effect was noted at a concentration of $5 \times 10^{-11} \mathrm{M}$ IGF-I (27\% stimulation) and was maximal at a concentration of 5 $\times 10^{-10}$ M IGF-I (46\% stimulation). There was no effect of luminal IGF-I on volume absorption or bicarbonate transport. These data indicate that growth hormone has no direct effect on PCT transport. In the PCT, IGF-I stimulates phosphate transport specifically and acts via both basolateral and apical membranes. However, the magnitude of the maximal response to the luminal addition of IGF-I was threefold greater than that measured upon addition of the hormone to the bath, and the stimulation occurred at a 100-fold lower concentration. These data are consistent with IGF-I mediating the in vivo stimulation of phosphate transport by growth hormone. (J. Clin. Invest. 1991. 88:368-374.) Key words: in vitro microperfusion • phosphate transport • bicarbonate transport • volume absorption
\end{abstract}

\section{Introduction}

There is substantial evidence that growth hormone affects renal function (1-13). Growth hormone excess, whether from endogenous hypersecretion or chronic exogenous administration, has been associated with an increase in renal blood flow, glomerular filtration rate (1-6), and increased levels of serum phosphate (7-9, 13-15). Administration of growth hormone to dogs increased glomerular filtration rate, serum phosphate, and the maximal rate of tubular phosphate reabsorption, effects independent of parathyroid hormone (8). Brush border membrane vesicles prepared from the renal cortex of dogs

Address correspondence to Dr. Michel Baum, Department of Pediatrics, University of Texas Southwestern Medical Center, 5323 Harry Hines Boulevard, Dallas, TX 75235-9063.

Received for publication 19 February 1991.

J. Clin. Invest.

(C) The American Society for Clinical Investigation, Inc.

0021-9738/91/08/0368/07 \$2.00

Volume 88, August 1991, 368-374 treated with growth hormone for $\mathbf{3} \mathrm{d}$ had an increase in sodium-dependent phosphate uptake (16). Likewise, hypophysectomized animals had a reduction in renal blood flow and glomerular filtration rate, effects reversed by growth hormone administration $(1,10,11)$. Selective growth hormone deficiency, induced by administration of a synthetic peptide antagonist to growth hormone releasing factor, resulted in a reduction in glomerular filtration rate and increased the fractional excretion of phosphate (12).

While chronic growth hormone administration produces renal hemodynamic changes and modulates phosphate transport, acute administration of growth hormone does not produce these changes $(5,6,17,18)$. Renal blood flow, glomerular filtration rate, and tubular reabsorption of phosphate remained stable $2 \mathrm{~h}$ after growth hormone administration in normal and thyroparathyroidectomized dogs (17). Similarly, renal blood flow and glomerular filtration rate remained stable for $6 \mathrm{~h}$ in man after growth hormone administration $(5,6,18)$. However, on the second and third day after a single injection of growth hormone, there was a rise in renal blood flow and glomerular filtration rate $(5,6)$. The increase in these parameters paralleled a rise in serum insulin-like growth factor I (IGF-I) ${ }^{1}$ levels, and occurred at a time when growth hormone levels had returned to normal. In normal human subjects, infusion of IGF-I increased creatinine clearance and decreased plasma creatinine and urea levels (19). IGF-I increased renal plasma flow and glomerular filtration rate in fasted rats within $\mathbf{4 0} \mathrm{min}$ of infusion (20). Thus, these studies suggest that the hemodynamic and tubular effects of growth hormone may be mediated by IGF-I.

The proximal tubule has both growth hormone and IGF-I receptors (21-25). It has been demonstrated recently that growth hormone has direct effects on this epithelium in the absence of IGF-I (22). Growth hormone produced an increase in phospholipase $\mathrm{C}$ activity when added to proximal tubular basolateral membranes. Addition of growth hormone to proximal tubule suspensions stimulated gluconeogenesis $(26,27)$ and ammoniagenesis (27). Whether growth hormone directly affects proximal tubule transport or acts indirectly via IGF-I is not known. The purpose of this in vitro microperfusion study was to determine if growth hormone and IGF-I can directly modulate transport in the proximal tubule.

\section{Methods}

Isolated segments of proximal convoluted tubules (PCT) were perfused as previously described $(28,29)$. Briefly, kidneys from female New

1. Abbreviations used in this paper: IGF-I, insulin-like growth factor I; $\mathrm{J}_{\text {Phos }}$, phosphate transport; $\mathrm{J}_{\mathrm{TCO} 2}$, bicarbonate transport; $\mathrm{PCT}$, proximal convoluted tubules; PD, potential difference. 


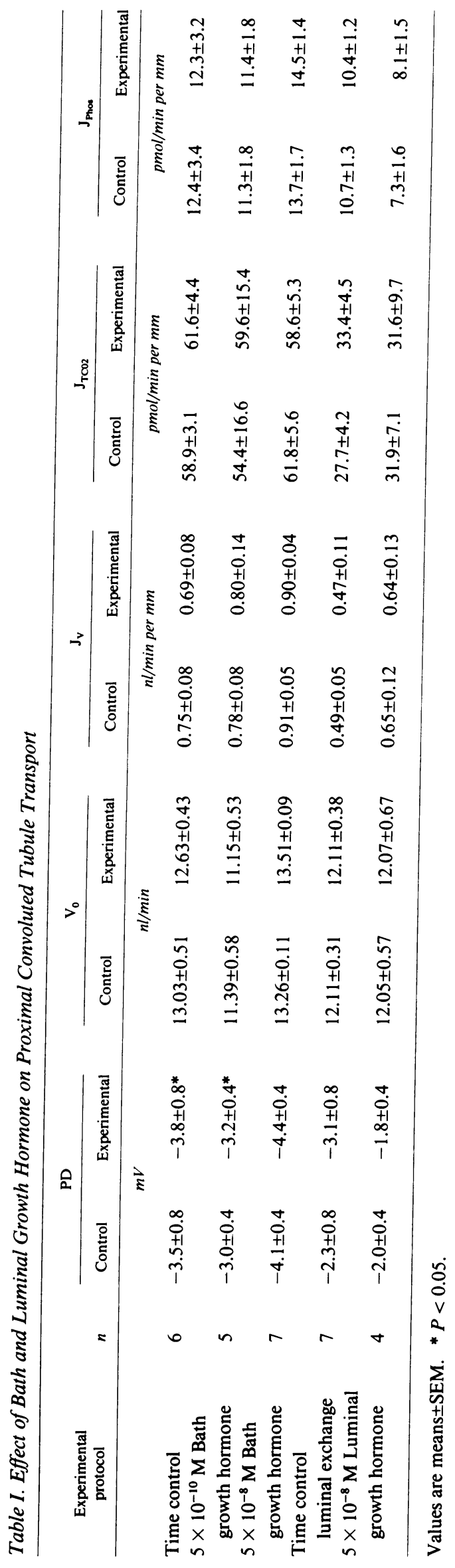

Zealand white rabbits were sliced in coronal sections. Individual PCT segments were dissected in a cooled $\left(4^{\circ} \mathrm{C}\right)$ ultrafiltrate-like solution which contained in mM: $115 \mathrm{NaCl}, 25 \mathrm{NaHCO}_{3}, 4 \mathrm{Na}_{2} \mathrm{HPO}_{4}, 10 \mathrm{Na}$ acetate, $1.8 \mathrm{CaCl}_{2}, 1 \mathrm{MgSO}_{4}, 5 \mathrm{KCl}, 8.3$ glucose, and 5 alanine. Tubules were then transferred to a 1.2 ml-temperature-controlled bath chamber and perfused with concentric glass pipettes.

Tubules were perfused with the above ultrafiltrate-like solution and bathed in a similar serum-like solution containing $6 \mathrm{~g} / \mathrm{dl}$ albumin. The osmolality of the bath and perfusate was adjusted to $295 \mathrm{mOsm} / \mathrm{kg}$ by adding either water or $\mathrm{NaCl}$. The bath was exchanged at a rate of 0.5 $\mathrm{ml} / \mathrm{min}$ to maintain a constant $\mathrm{pH}$ and osmolality. The bath temperature was $37^{\circ}-38^{\circ} \mathrm{C}$. After a 60 -min equilibration period, the control period was begun. Subsequent periods were separated by $30 \mathrm{~min}$ of equilibration. To ensure that the albumin containing bathing solution had no growth hormone or IGF-I contaminants, samples of bath solution were sent to two independent laboratories (Nichols Institute, Irving, TX, and Endocrine Sciences, Tarzana, CA) for determination of growth hormone and IGF-I content. Both of these substances were found to be below the detectable limits of the assay $\left(<2.7 \times 10^{-11} \mathrm{M}\right.$ growth hormone and $<1.3 \times 10^{-10} \mathrm{M}$ IGF-I).

Volume absorption (in nanoliters per minute per millimeter) was calculated as the difference between perfusion $\left(V_{o}\right)$ and collection $\left(V_{L}\right)$ rates, and normalized per millimeter of tubule length $(\mathrm{L})$. Exhaustively dialyzed [methoxy- ${ }^{3} \mathrm{H}$ ] inulin was added to the perfusate at a concentration of $50 \mu \mathrm{Ci} / \mathrm{ml}$ so that the perfusion rate could be determined. The collection rate was measured by timed collections using a constant volume pipette. The length (in millimeters) was measured using an eyepiece micrometer.

Bicarbonate transport $\left(\mathrm{J}_{\mathrm{TCO} 2}\right.$, picomoles per minute per millimeter) was calculated using the equation: $\mathrm{J}_{\mathrm{TCO}_{2}}=\left(\mathrm{V}_{0} \mathrm{C}_{0}-\mathrm{V}_{\mathrm{L}} \mathrm{C}_{\mathrm{L}}\right) / \mathrm{L}$, where $\mathrm{C}_{0}$ and $C_{L}$ represent the bicarbonate concentrations in the perfusate and collected fluid, respectively. Bicarbonate was measured using microcalorimetry (picapnotherm, model GVI; World Precision Instruments, Inc., New Haven, CT) (30).

Phosphate transport $\left(\mathrm{J}_{\text {Phos }}\right.$, picomoles per minute per millimeter) was measured using perfusate ${ }^{32} \mathrm{PO}_{4}(50 \mu \mathrm{Ci} / \mathrm{ml})$. Phosphate transport was then calculated using the equation: $J_{\text {Phos }}=\left[\left(V_{O} C_{0}^{*}-V_{L} C_{L}^{*}\right) / L\right]$ $\left(\mathrm{P}_{\mathrm{O}} / \mathrm{C}_{0}^{*}\right)$, where $\mathrm{P}_{\mathrm{O}}$ is the phosphate concentration in the perfusate and $\mathrm{C}_{0}^{*}$ and $\mathrm{C}_{\mathrm{L}}^{*}$ are the concentrations of ${ }^{32} \mathrm{PO}_{4}$ in the perfusate and collected fluid, respectively, in counts per minute per nanoliter.

The transepithelial potential difference (PD, millivolts) was measured by using the perfusion pipette as the bridge into the tubular lumen. The perfusion and bathing solutions were connected to the recording and reference calomel half-cells using a bridge containing the perfusate in series with a $3.6 \mathrm{M} \mathrm{KCl} / 0.9 \mathrm{M} \mathrm{KNO}_{3}$ agarose bridge. This arrangement avoided direct contact between the $\mathrm{KCl} / \mathrm{KNO}_{3}$ agarose bridge and the solution bathing the tubule. The recording and reference calomel half-cells were connected to the high and low impedance sides, respectively, of an electrometer (model 602; Keithley Instruments, Inc., Cleveland, $\mathrm{OH}$ ).

To determine if growth hormone (Eli Lilly, Indianapolis, IN) directly affects PCT transport, tubules were perfused with an ultrafiltratelike solution and bathed in a serum-like albumin solution. During the experimental period either $0,5 \times 10^{-10}$, or $5 \times 10^{-8} \mathrm{M}$ growth hormone was added to the bath. $5 \times 10^{-8} \mathrm{M}$ growth hormone was added to the luminal perfusate in additional studies to determine if growth hormone had a direct effect on the apical membrane.

To determine if bath IGF-I affects PCT transport, tubules were again perfused with an ultrafiltrate-like solution and bathed in a serumlike albumin solution. During the experimental period either 0,5 $\times 10^{-10}, 5 \times 10^{-9}$, or $5 \times 10^{-8} \mathrm{M}$ IGF-I (Amgen Biologicals, Thousand Oaks, CA) was added to the bathing solution. Because IGF-I is known to cause phosphorylation of its own receptor and subsequent phosphorylation of other intracellular proteins, an apparent increase in $\mathrm{J}_{\text {Phos }}$ could be due to an increase in cellular uptake and utilization of phosphate, and not to an increase in the transepithelial transport of phosphate. To examine this possibility, ${ }^{32} \mathrm{PO}_{4}$ accumulation in the bath was measured in a series of tubules incubated with $5 \times 10^{-8} \mathrm{M}$ bath IGF-I. 
Three 1-ml samples of bath from both the control and experimental periods were counted for ${ }^{32} \mathrm{PO}_{4}$ and then averaged for each experiment. The lumen to bath flux of phosphate was then calculated from the rate of appearance of ${ }^{32} \mathrm{PO}_{4}$ in the bath. In the last series of experiments IGF-I was added to the luminal perfusate to determine if IGF-I had an effect on transport via the apical membrane. During the experimental period either $0,5 \times 10^{-12}, 5 \times 10^{-11}, 5 \times 10^{-10}$, or $5 \times 10^{-8} \mathrm{M}$ IGF-I was added to the luminal perfusate.

There were four to six measurements of PD, volume absorption, bicarbonate transport, and phosphate transport in each period in all tubules. The mean value for individual periods in a given tubule was used to calculate the mean for that period. Data are expressed as mean \pm SEM. The $t$ test for paired data was used to determine significance at the 0.05 level.

\section{Results}

Effect of lumen and bath growth hormone on PCT transport. The first series of experiments examined whether growth hormone has a direct effect on PCT transport. These results are shown in Table I. The mean tubular length for these experiments was $1.5 \pm 0.1 \mathrm{~mm}$. Time controls were done to ensure the stability of our preparation. In these experiments vehicle, rather than hormone, was added during the experimental period. There was a small but statistically significant increase in the PD with time, but volume absorption, phosphate and bicarbonate transport remained constant. An increase in PD with time has been found previously in the in vitro PCT (31, 32). A physiologic concentration of bath growth hormone (5 $\times 10^{-10} \mathrm{M}$ ) had no effect on volume absorption, bicarbonate or phosphate transport, but caused a small significant increase in $\mathrm{PD}$, comparable to that observed in the time control studies. The concentration of growth hormone used was similar to peak plasma levels in humans during puberty (33), and to the concentration that caused half-maximal stimulation of phospholipase $\mathrm{C}$ activity in canine proximal tubular basolateral membranes (22). A pharmacologic concentration of growth hormone $\left(5 \times 10^{-8} \mathrm{M}\right)$ also had no effect on PCT volume absorption, or bicarbonate or phosphate transport when added to the bath.

Because growth hormone is filtered, the effect of luminal growth hormone was also examined $(34,35)$. Addition of 5 $\times 10^{-8} \mathrm{M}$ growth hormone to the luminal perfusate had no effect on PCT transport (Table I). Time controls with luminal perfusate exchanges, done to ensure that the luminal exchange did not affect transport, demonstrated no significant effect on PCT transport. Thus, neither physiologic nor pharmacologic doses of growth hormone had an effect on PCT volume absorption, or the transport of bicarbonate and phosphate.

Effect of lumen and bath IGF-I on PCT transport. The next series of experiments examined the effect of bath IGF-I on PCT transport. During the experimental period, IGF-I was added to the bath in concentrations of $5 \times 10^{-10} \mathrm{M}, 5 \times 10^{-9} \mathrm{M}$, or 5 $\times 10^{-8} \mathrm{M}$. This range includes the concentration that results in half-maximal occupancy of IGF-I receptors in the proximal tubule (23-25). The results are shown in Table II and Fig. 1. The mean tubular length in these studies was $1.4 \pm 0.1 \mathrm{~mm}$. When $5 \times 10^{-9} \mathrm{M}$ IGF-I was added to the bath, there was a small but statistically significant increase in $\mathrm{PD}$, comparable to that seen in the time control experiments. There was also a small but statistically significant increase in volume absorption during the studies examining the effects of $5 \times 10^{-9} \mathrm{M}$ bath

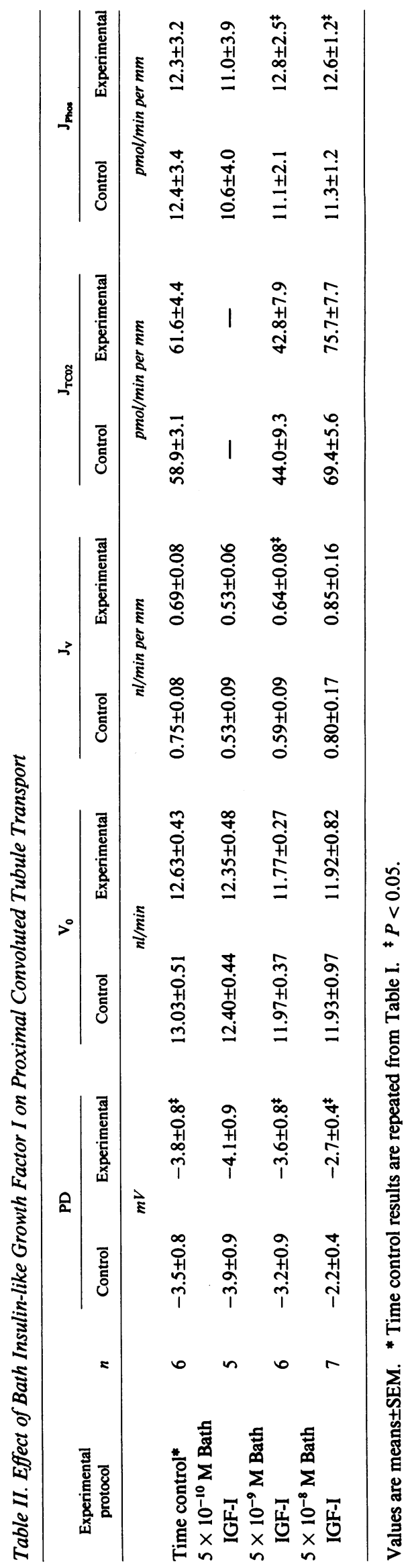




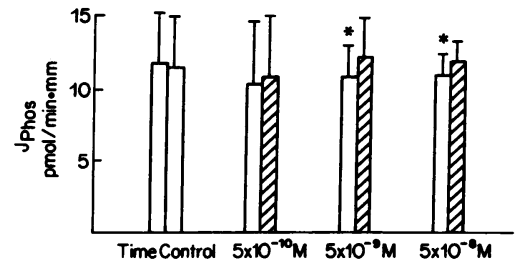

Figure 1. Effect of bath IGF-I on PCT phosphate transport. $* P$ $<0.05$. $\square$ control, IGF-I.

IGF-I, but there was no effect on volume absorption at bath IGF-I concentrations of $5 \times 10^{-10} \mathrm{M}$ and $5 \times 10^{-8} \mathrm{M}$. There was no change in bicarbonate transport at any bath IGF-I concentration. However, $5 \times 10^{-9} \mathrm{M}$ and $5 \times 10^{-8} \mathrm{M}$ IGF-I stimulated phosphate transport by $15 \%$ and $12 \%$, respectively. Thus, bath IGF-I causes a significant increase in phosphate transport, but no significant change in bicarbonate absorption.

To determine if the increase in phosphate transport was due to an increase in uptake and metabolism of phosphate, or to a true increase in transepithelial transport, the bathing solution was analyzed for ${ }^{32} \mathrm{PO}_{4}$ in three of the experiments examining the effect of $5 \times 10^{-8} \mathrm{M}$ bath IGF-I on proximal tubule transport. These results are shown in Table III. The lumen to bath flux of phosphate was calculated from the appearance rate of ${ }^{32} \mathrm{PO}_{4}$ in the bath. These data are in close agreement to the fluxes calculated from the perfused and collected fluid phosphate concentrations, confirming that there was a significant increase in transepithelial phosphate transport in the presence of bath IGF-I.

The last series of experiments examined the effect of luminal IGF-I on PCT transport. During the experimental period $5 \times 10^{-12} \mathrm{M}, 5 \times 10^{-11} \mathrm{M}, 5 \times 10^{-10} \mathrm{M}$, or $5 \times 10^{-8} \mathrm{M}$ IGF-I was added to the luminal perfusate. These results are shown in Table IV and Fig. 2. The mean tubular length in these studies was $1.4 \pm 0.1 \mathrm{~mm}$. There were no significant changes in $\mathrm{PD}$, volume absorption, or bicarbonate transport, except for a small but statistically significant increase in $\mathrm{J}_{\mathrm{TCO} 2}(26.4 \pm 2.6$ to $31.2 \pm 2.3 \mathrm{pmol} / \mathrm{min}$ per $\mathrm{mm}, P<0.05$ ) with $5 \times 10^{-11} \mathrm{M}$ luminal IGF-I. At $5 \times 10^{-12} \mathrm{M}$ luminal IGF-I there was no effect on phosphate transport. At $5 \times 10^{-11} \mathrm{M}$ luminal IGF-I there was a $26.8 \%$ stimulation of phosphate transport. The stimulation in phosphate transport was maximal at a luminal concentration of $5 \times 10^{-10} \mathrm{M}$ IGF-I (46\%), with no further stimulation at $5 \times 10^{-8} \mathrm{M}$ IGF-I. Thus, luminal IGF-I significantly increases phosphate transport in the proximal tubule. The luminal effect of IGF-I occurs at a much lower IGF-I concentration, and produces a greater stimulation than that observed with bath IGF-I.

Table III. Effect of Bath IGF-1 on 32 P Counts Appearing in the Bath

\begin{tabular}{lccc}
\hline \multicolumn{1}{c}{$\begin{array}{c}\text { Experimental } \\
\text { protocol }\end{array}$} & $n$ & $\begin{array}{c}{ }^{32} \mathrm{P} \text { counts } \\
\text { mean } \pm \text { SEM }\end{array}$ & $\mathrm{J}_{\text {poos }}{ }^{*}$ \\
& & $c p m / m l$ & $p m o l / m i n \cdot m m$ \\
Control & 3 & $160.3 \pm 67.1$ & $9.0 \pm 2.1$ \\
$5 \times 10^{-8}$ M Bath IGF-1 & 3 & $177.6 \pm 70.7^{\ddagger}$ & $10.2 \pm 2.5^{5}$
\end{tabular}

${ }^{*} \mathrm{~J}_{\text {phos }}$ calculated from rate of appearance of ${ }^{32} \mathrm{P}$ in the bath. ${ }^{\ddagger} P$ $<0.01 ;{ }^{8} P<0.05$.

\section{Discussion}

This in vitro microperfusion study examined the effects of growth hormone and IGF-I on proximal convoluted tubule transport. Growth hormone had no direct effect on PCT volume absorption, phosphate or bicarbonate transport at either physiologic $\left(5 \times 10^{-10} \mathrm{M}\right)$ or pharmacologic $\left(5 \times 10^{-8} \mathrm{M}\right)$ concentrations. However, addition of IGF-I to the bathing solution resulted in a dose-dependent increase in phosphate transport, with no change in volume absorption or bicarbonate transport. Addition of IGF-I to the luminal perfusate resulted in a dosedependent stimulation of PCT phosphate transport with no change in volume absorption or bicarbonate transport. 5 $\times 10^{-12} \mathrm{M}$ IGF-I in the luminal perfusate had no effect on phosphate transport, but there was a stimulation of phosphate transport at higher concentrations of IGF-I. Maximal stimulation of phosphate transport occurred at $5 \times 10^{-10} \mathrm{M}$ luminal IGF-I. These data demonstrate that growth hormone has no direct effect on PCT transport. However, IGF-I directly stimulates PCT phosphate transport, an effect which can be mediated from both the basolateral and apical membranes.

Receptors for growth hormone are present on the proximal tubule $(21,22)$. Growth hormone has been shown to bind to receptors present in the basolateral membrane vesicles isolated from canine renal cortex and stimulate phospholipase $\mathrm{C}$ activity (22). Half-maximal stimulation of phospholipase $\mathrm{C}$ activity occurred at $5 \times 10^{-10} \mathrm{M}$ growth hormone and was noted within $15 \mathrm{~s}$ of incubation with growth hormone. Growth hormone has been shown to stimulate gluconeogenesis in rat kidney cortical slices (36), and in suspensions of canine proximal tubules (26, 27). In these latter studies $10^{-6} \mathrm{M}$ growth hormone increased glucose production by $55 \%$ after $120 \mathrm{~min}$ of incubation. The half-maximal response occurred between $10^{-9} \mathrm{M}$ and $10^{-8} \mathrm{M}$ growth hormone $(26,27)$. Growth hormone also increased ammoniagenesis, where half-maximal stimulation occurred at a concentration between $10^{-10} \mathrm{M}$ and $10^{-9} \mathrm{M}$ (27).

The acute effect of growth hormone on tubular phosphate reabsorption has been examined in dogs (17). Dogs received a growth hormone infusion for $2 \mathrm{~h}$, then inulin and para-aminohippurate clearances and phosphate reabsorption were measured over the subsequent $2 \mathrm{~h}$. There was no significant change in renal blood flow, glomerular filtration rate, or tubular reabsorption of phosphate in these dogs, results which agree with our findings. In this study, the concentrations of growth hormone used are well within the range of those that have been previously reported to stimulate phospholipase $\mathrm{C}$ activity, gluconeogenesis, and ammoniagenesis in the proximal tubule (22, $26,27,36)$. The total time of incubation with growth hormone during the experimental period was $90-120 \mathrm{~min}$. This is comparable to the time of incubation where growth hormone has been shown to increase ammoniagenesis and gluconeogenesis $(26,27,36)$.

Serum IGF-I levels increase after growth hormone administration and could mediate the effects of growth hormone on phosphate transport. Hypophysectomized rats given IGF-I via osmotic minipump for $6 \mathrm{~d}$ had an elevated serum phosphate and an increased maximal rate of tubular reabsorption of phosphate (37). Brush border membrane vesicles isolated from the renal cortex of these animals had a higher Na-dependent Pi transport, compared to vehicle treated controls. Sodium-dependent glucose and alanine uptake were not affected. The stimulatory effect of IGF-I on maximal rate of tubular reab- 
sorption of phosphate was also observed in thyroparathyroidectomized animals indicating that IGF-I's action was independent of parathyroid hormone.

Serum 1,25-dihydroxyvitamin $D_{3}$ levels have correlated well with serum IGF-I levels under a number of experimental conditions $(38,39)$. Infusion of IGF-I in hypophysectomized rats increased serum 1,25-dihydroxyvitamin $D_{3}$ levels (37). Since 1,25-dihydroxyvitamin $D_{3}$ stimulates phosphate transport $(40,41)$, the effect of IGF-I in vivo could have been mediated by 1-25-dihydroxyvitamin $D_{3}$. Our study, however, demonstrates a stimulation of phosphate transport by IGF-I in the absence of 1,25-dihydroxyvitamin $\mathrm{D}_{3}$.

The acute effect of IGF-I on phosphate transport has been studied in a cell culture line derived from opossum kidneys (42). These cells have sodium-dependent phosphate transport that is inhibited by parathyroid hormone $(43,44)$. IGF-I stimulated sodium-dependent phosphate uptake within $15 \mathrm{~min}$ of incubation (42). Half-maximal stimulation occurred at a dose of $10^{-9} \mathrm{M}$ IGF-I, and maximal stimulation was found at $10^{-7}$ M IGF-I. Kinetic analysis demonstrated an increase in $V_{\max }$ with no change in the $K_{\mathrm{m}}$ for phosphate transport. It was also noted that the effect was specific for phosphate transport since the transport of alanine was not affected.

These studies examined the effect of IGF-I on proximal tubule transport. In vitro microperfusion of individual PCT demonstrated that bath IGF-I stimulated phosphate transport, but did not change volume absorption or bicarbonate transport. The concentration of bath IGF-I that increased phosphate transport $\left(5 \times 10^{-9} \mathrm{M}\right)$ was similar to that found in the cell culture studies (42). This concentration of IGF-I was that required for half-maximal binding to IGF-I receptors on basolateral membranes (23-25), and the concentration that caused autophosphorylation of the $\beta$-subunit of the IGF-I receptor (45).

Receptors for IGF-I are present on both the basolateral and apical membranes of the proximal tubule with the density of receptors greater on the basolateral membrane (24). Incubation of basolateral membrane vesicles (but not brush border membrane vesicles) with IGF-I resulted in phosphorylation of the receptor indicating an intracellular signalling process linked to IGF-I (24). These data indicate that, while IGF-I receptors are present on the apical membrane, they may not function by the same intracellular signal transduction mechanism as those on the basolateral membrane. The present study demonstrates that IGF-I does have a direct effect to stimulate phosphate transport when presented to the apical membrane.

The significance of the IGF-I effect on the apical membrane is not clear. IGF-I has a mol wt of $\sim 7,500$ and thus could be filtered by the glomerulus. However, most of the IGF-I in the serum is tightly bound to carrier proteins $(46,47)$. The unbound fraction of IGF-I has been estimated to be $0.1-0.8 \%$ of the total $(46,47)$. The circulating concentration of IGF-I is $\sim 10^{-7} \mathrm{M}$. Thus, if only $0.1 \%$ of IGF-I is free, $10^{-10} \mathrm{M}$ IGF-I could be in the glomerular ultrafiltrate. This concentration is within the range that stimulated phosphate transport in this study. Recently, studies have found that mesangial cells are capable of synthesizing IGF-I (48). This raises the possibility that mesangial cells could play a role in the regulation of proximal tubule phosphate transport.

IGF-I is produced by several organs in the body including the liver, lungs, heart, and kidneys (49). The tissue concentrations of IGF-I in these organs decreases with hypophysectomy

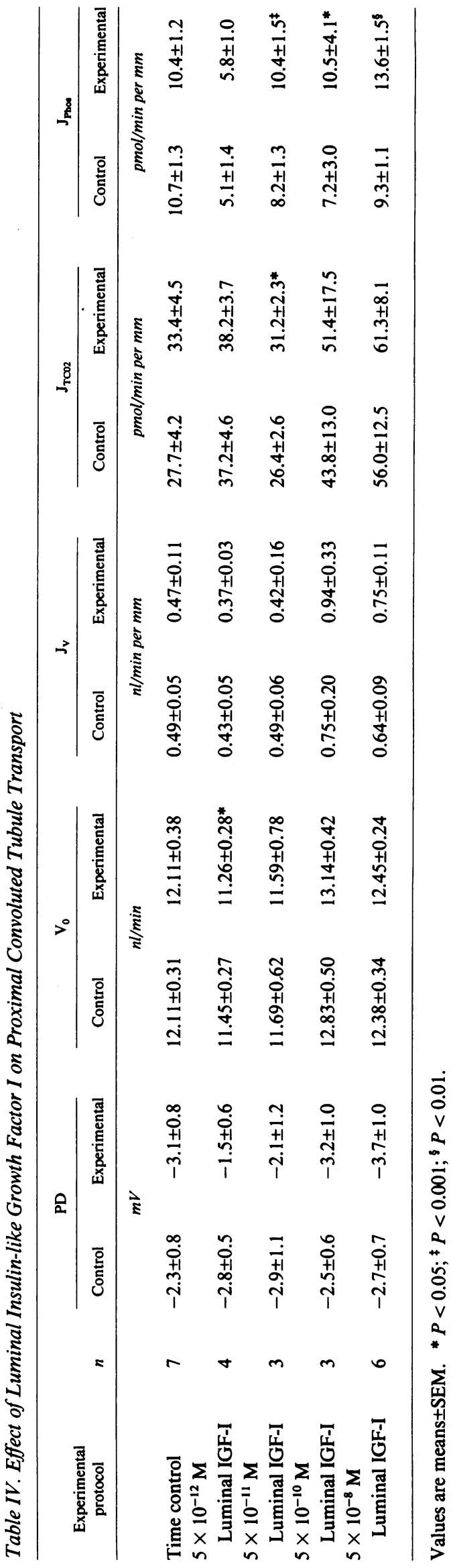




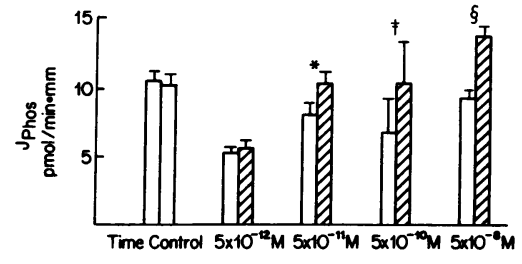

Figure 2. Effect of luminal IGF-I on PCT phosphate transport. *P $<0.001 ;{ }^{\ddagger} P<0.05 ;{ }^{8} P$ $<0.01$. $\square$ control, IGF-I.

and increases when the animal is treated with growth hormone. Recent evidence has shown that rat collecting ducts produce IGF-I in direct response to growth hormone (50). The significance of this finding is not clear. The major site of phosphate transport is the proximal tubule. It has been postulated that the IGF-I from the collecting duct cells may traverse the interstitium or travel via the vasa rectae to capillaries surrounding the proximal tubule (21). In this manner IGF-I synthesized by the distal nephron may influence phosphate transport by the proximal tubule.

This in vitro microperfusion study directly addressed the issue of whether growth hormone or IGF-I affects proximal tubular transport. These studies were performed in the rabbit PCT and species differences are possible. However, our study demonstrates that while growth hormone had no effect on PCT transport, IGF-I stimulated directly phosphate transport in the rabbit PCT. This stimulation is specific for phosphate as volume absorption and bicarbonate transport remained unchanged. The stimulation in transport by IGF-I is much greater when presented to the apical membrane and suggests that apical receptors may play an important role in the regulation of phosphate transport in the proximal tubule.

\section{Acknowledgments}

We are grateful for the technical assistance of Rebecca Aricheta and Ebtisam Shawky, and the able secretarial assistance of Janell McQuinn.

This work is supported by National Institutes of Health grants R29DK38465-01 and DK 41612-01, and American Heart Association grant 890664. Dr. Quigley was a National Kidney Foundation Fellow (1989-1990) and an N.I.H. Fellow T32 DK07257 (1990-1991) during these studies. Growth hormone was a generous gift from Eli Lilly.

\section{References}

1. White, H. L., P. Heinbecker, and D. Rolf. 1949. Enhancing effects of growth hormone on renal function. Am. J. Physiol. 157:47-51.

2. Ikkos, D., H. Ljunggren, and R. Luft. 1956. Glomerular filtration rate and renal plasma flow in acromegaly. Acta Endocrinol. 21:226-236.

3. Gershberg, H., H. O. Heinemann, and H. H. Stumpf. 1957. Renal function studies and autopsy report in a patient with gigantism and acromegaly. J. Clin. Endo. Med. 17:377-385.

4. Christiansen, J. S., J. Gammelgaard, H. Ørskov, A. R. Andersen, S. Telmer, and H.-H. Parving. 1981. Kidney function and size in normal subjects before and during growth hormone administration for one week. Eur. J. Clin. Invest. 11:487-490.

5. Hirschberg, R. R., and J. D. Kopple. 1988. Increase in renal plasma flow and glomerular filtration rate during growth hormone treatment may be mediated by insulin-like growth factor I. Am. J. Nephrol. 8:249-253.

6. Hirschberg, R., H. Rabb, R. Bergamo, and J. D. Kopple. 1989. The delayed effect of growth hormone on renal function in humans. Kidney Int. 35:865-870.

7. Corvilain, J., and M. Abramow. 1962. Some effects of human growth hormone on renal hemodynamics and on tubular phosphate transport in man. $J$. Clin. Invest. 41:1230-1235.

8. Corvilain, J., and M. Abramow. 1964. Effect of growth hormone on tubular transport of phosphate in normal and parathyroidectomized dogs. J. Clin. Invest. 43:1608-1612.
9. Camanni, F., F. Massara, O. Losana, and G. M. Molinatti. 1968. Increased renal tubular reabsorption of phosphorous in acromegaly. J. Clin. Endocrinol. \& Metab. 28:999-1005.

10. Falkheden, T. 1963. Renal function following hypophysectomy in man. Acta Endocrinol. 42:571-590.

11. Falkheden, T., and I. Wickbom. 1965. Renal function and kidney size following hypophysectomy in man. Acta Endocrinol. 48:348-354.

12. Mulroney, S. E., M. D. Lumpkin, and A. Haramati. 1989. Antagonist to growth hormone-releasing factor inhibits growth and renal $P_{i}$ reabsorption in immature rats. Am. J. Physiol. 257:F29-F34.

13. Henneman, P. H., A. P. Forbes, M. Moldawer, E. F. Dempsey, and E. L. Carroll. 1960. Effects of human growth hormone in man. J. Clin. Invest. 39:1223-1238.

14. Reifenstein, E. C., Jr., L. W. Kinsell, and F. Albright. 1946. Observations on the use of the serum phosphorus level as an index of pituitary growth hormone activity: the effect of estrogen therapy in acromegaly. Endocrinology. 39:71. (Abstr.)

15. Li, C. H., I. Geschwind, and H. M. Evans. 1949. The effect of growth hormone on the inorganic phosphorus levels in the plasma. Endocrinology. 44:67-70.

16. Hammerman, M. R., I. E. Karl, and K. A. Hruska. 1980. Regulation of canine renal vesicle $P_{1}$ transport by growth hormone and parathyroid hormone. Biochim. Biophys. Acta. 603:322-335.

17. Westby, G. R., S. Goldfarb, M. Goldberg, and Z. S. Agus. 1977. Acute effects of bovine growth hormone on renal calcium and phosphate excretion. Metab. Clin. Exp. 26:525-530.

18. Parving, H.-H., I. Noer, C. E. Mogensen, and P. Aa. Svendsen. 1978. Kidney function in normal man during short-term growth hormone infusion. Acta Endocrinol. 89:796-800.

19. Guler, H. P., C. Schmid, J. Zapf, and E. R. Froesch. 1989. Effects of recombinant insulin-like growth factor I on insulin secretion and renal function in normal human subjects. Proc. Natl. Acad. Sci. USA. 86:2868-2872.

20. Hirschberg, R., and J. D. Kopple. 1989. Evidence that insulin-like growth factor I increases renal plasma flow and glomerular filtration rate in fasted rats. $J$. Clin. Invest. 83:326-330.

21. Hammerman, M. R. 1989. The growth hormone-insulin-like growth factor axis in kidney. Am. J. Physiol. 257:F503-F514.

22. Rogers, S. A., and M. R. Hammerman. 1989. Growth hormone activates phospholipase $C$ in proximal tubular basolateral membranes from canine kidney. Proc. Natl. Acad. Sci. USA. 86:6363-6366.

23. Hammerman, M. R., and J. R. Gavin III. 1986. Binding of IGF I and IGF I-stimulated phosphorylation in canine renal basolateral membranes. Am. J. Physiol. 251:E32-E41.

24. Hammerman, M. R., and S. Rogers. 1987. Distribution of IGF receptors in the plasma membrane of proximal tubular cells. Am. J. Physiol. 253:F841F847.

25. Pillion, D. J., J. F. Haskell, and E. Meezan. 1988. Distinct receptors for insulin-like growth factor $\mathrm{I}$ in rat renal glomeruli and tubules. Am. J. Physiol. 255:E504-E512.

26. Rogers, S. A., I. E. Karl, and M. R. Hammerman. 1989. Growth hormone directly stimulates gluconeogenesis in canine renal proximal tubule. Am. J. Physiol. 257:E751-E756.

27. Chobanian, M. C., and C. M. Julin. 1990. Growth hormone stimulates ammoniagenesis and gluconeogenesis in canine proximal tubule segments. Kidney Int. 37:526. (Abstr.)

28. Burg M. B., J. Grantham, M. Abramow, and J. Orloff, 1966. Preparation and study of fragments of single rabbit nephrons. Am. J. Physiol. 210:1293-1298.

29. Baum, M. 1987. Insulin stimulates volume absorption in the rabbit proximal convoluted tubule. J. Clin. Invest. 79:1104-1109.

30. Vureck, G. G., D. G. Warnock, and R. Corsey. 1975. Measurement of picomole amounts of carbon dioxide by calorimetry. Anal. Chem. 47:765-767.

31. Schuster, V. L., J. P. Kokko, and H. R. Jacobson. 1984. Angiotensin II directly stimulates sodium transport in rabbit proximal convoluted tubules. $J$. Clin. Invest. 73:507-515.

32. Baum, M., and S. R. Hays. 1988. Phorbol myristate acetate and dioctanoylglycerol inhibit transport in rabbit proximal convoluted tubule. $\mathrm{Am}$. J. Physiol. 254:F9-F14.

33. Greenwood, F. C., W. M. Hunter, and V. J. Marrian. Growth-hormone levels in children and adolescents. 1964. Br. Med. J. 1:25-26.

34. Johnson, V., and T. Maack. 1977. Renal extraction, filtration, absorption, and catabolism of growth hormone. Am. J. Physiol. 233:F185-F196.

35. Rabkin, R., T. I. Gottheiner, and V. S. Fang. 1981. Removal and excretion of immunoreactive rat growth hormone by the isolated kidney. Am. J. Physiol. 240:F282-F287.

36. Joseph, P. K., and K. Subrahmanyam. 1968. Effect of growth hormone, insulin, thyroxine and cortisone on renal gluconeogenesis. Arch. Biochem. Biophys. 127:288-291. 
37. Caverzasio, J., C. Montessuit, and J. P. Bonjour. 1990. Stimulatory effect of insulin-like growth factor-I on renal Pi transport and plasma 1,25-dihydroxyvitamin $D_{3}$. Endocrinology. 127:453-459.

38. Gray, R. W. 1987. Evidence that somatomedins mediate the effect of hypophosphatemia to increase serum 1,25-dihydroxyvitamin $D_{3}$ levels in rats. Endocrinology. 121:504-512.

39. Halloran, B. P., and E. M. Spencer. 1988. Dietary phosphorus and 1,25dihydroxyvitamin D metabolism: influence of insulin-like growth factor I. Endocrinology. 123:1225-1229.

40. Liang, C. T., J. Barnes, R. Balakir, L. Cheng, and B. Sacktor. 1982. In vitro stimulation of phosphate uptake in isolated chick renal cells by 1,25 -dihydroxycholecalciferol. Proc. Natl. Acad. Sci. USA. 79:3532-3536.

41. Kurnik, B. R. C., and K. A. Hruska. 1984. Effects of 1,25-dihydroxycholecalciferol on phosphate transport in vitamin D-deprived rats. Am. J. Physiol. 247:F177-F182.

42. Caverzasio, J., and J.-P. Bonjour. 1989. Insulin-like growth factor I stimulates Na-dependent $\mathrm{P}_{\mathrm{i}}$ transport in cultured kidney cells. Am. J. Physiol. 257:F712-F717.

43. Caverzasio, J., R. Rizzoli, and J. P. Bonjour. 1986. Sodium-dependent phosphate transport inhibited by parathyroid hormone and cyclic AMP stimulation in an opossum kidney cell line. J. Biol. Chem. 261:3233-3237.

44. Malmström, K., and H. Murer. 1986. Parathyroid hormone inhibits phos- phate transport in OK cells but not in LLC-PK, and JTC-12.P3 cells. Am. J. Physiol. 251:C23-C31.

45. Jacobs, S., F. C. Kull, Jr., H. S. Earp, M. E. Svoboda, J. J. Van Wyk, and P. Cuatrecasas. 1983. Somatomedin-C stimulates the phosphorylation of the $\beta$-subunit of its own receptor. J. Biol. Chem. 258:9581-9584.

46. Heinrich, U. E., D. S. Schalch, J. G. Koch, and C. J. Johnson. 1978. Nonsuppressible insulin-like activity (NSILA). II. Regulation of serum concentrations by growth hormone and insulin. J. Clin. Endocrinol. \& Metab. 46:672678.

47. Doughaday, W. H., A. P. Ward, A. C. Goldberg, B. Trivedi, and M. Kapadia. 1982. Characterization of somatomedin binding in human serum by ultracentrifugation and gel filtration. J. Clin. Endocrinol. \& Metab. 55:916-921.

48. Conti, F. G., L. J. Striker, S. J. Elliot, D. Andreani, and G. E. Striker. 1988 Synthesis and release of insulin-like growth factor I by mesangial cells in culture. Am. J. Physiol. 255:F1214-F1219.

49. D'Ercole, A. J., A. D. Stiles, and L. E. Underwood. 1984. Tissue concentrations of somatomedin C: further evidence for multiple sites of synthesis and paracrine or autocrine mechanisms of action. Proc. Natl. Acad. Sci.' USA. 81:935-939.

50. Rogers, S. A., S. B. Miller, and M. R. Hammerman. 1990. Growth hormone stimulates IGF I gene expression in isolated rat renal collecting duct. Am. J. Physiol. 259:F474-F479. 